\title{
PENGARUH KOMPETENSI PEDAGOGIK GURU DAN PENERAPAN METODE QIRAATI TERHADAP KEMAMPUAN BACA AL-QUR'AN
}

\author{
Dr. Saat Safaat, M.Pd.I \\ Universitas MH. Thamrin
}

\begin{abstract}
ABSTRAK
Berdasarkan studi pendahuluan pada siswa Madrasah Ibtidaiyah Terpadu (MIT) Nurul Iman, Tanah Baru, Depok. Diperoleh keterangan bahwa kompetensi pedagogik guru dan penerapan metode Qiraati dalam proses pembelajaran sudah baik akan tetapi masih ada siswa yang kurang dalam kemampuan baca Al-Qur'an. Berdasarkan fenomena empirik yang terjadi dilapangan maka penulis merasa tertarik untuk mengetahui pengaruh kompetensi pedagogik guru dan penerapan metode Qiraati terhadap kemampuan baca Al-Qur'an.Tujuan penelitian ini untuk mengetahui pengaruh kompetensi pedagogik guru terhadap kemampuan baca Al-Qur'an dan pengaruh penerapan metode Qiraati terhadap kemampuan baca Al-Qur'an. Populasi dalam penelitian ini adalah siswa Madrasah Ibtidaiyah Terpadu (MIT) Nurul Iman, Tanah Baru, Kecamatan Beji, Kota Depok yang berjumlah 450 siswa, sedangkan sampelnya berjumlah 115 siswa. Intrumen penelitian yang digunakan diantaranya adalah angket, observasi, wawancara, dan dokumen. Adapun teknik analisis data yang digunakan adalah dengan pengujian persyaratan analisis, pengujian hipotesis, dan mendescripsikan hasil penelitian.Berdasarkan hasil penelitian diperoleh keterangan bahwa: 1)Variabel Kompetensi Pedagogik guru memberikan pengaruh nyata terhadap kemampuan baca Al-Qur'an dengan nilai korelasi sebesar $73,8 \%$ 2). Variabel penerapan metode Qiraati memberikan pengaruh nyata terhadap kemampuan baca Al-Qur'an dengan nilai korelasi sebesar 57,0\% dan 3). Kompetensi pedagogik guru dan penerapan metode Qiraati memberi pengaruh terhadap kemampuan baca AlQur`an dengan nilai koefisiensi korelasi sebesar 57,1\%. Ini memberikan makna bahwa kemampuan baca Al-Qur'an sangat dipengaruhi oleh kompetensi pedagogik guru dan penerapan metode Qiraati yang baik, sehingan harus dikembangkan terus menerus agar kemampuan baca Al-Qur`an makin baik, benar dan meningkat.
\end{abstract}

Kata kunci: Kemampuan Baca Al-Quran, Kompetensi Pedagogik, dan Metode Qiraati

\section{A. Latar Belakang Masalah}

Al-Qur'an merupakan dasar keyakinan dalam agama dan membimbing manusia dalam kehidupan, sehingga sangat layak bila Al-Qur'an mendapat perhatian istimewa.Sekarang ini sangat prihatin sekali, Al-Qur'an telah hilang dari pendengaran kita, jarang sekali Al-Qur'an dikumandangkan di masjid dan di musholla dikarenakan semakin hari zaman semakin berkembang, kini orang tua selalu dibayangi oleh persepsi adanya dikotomi ilmu, yaitu duniawi (sekuler) dan ilmu agama dan pada kedua ilmu itu terdapat perbedaan yang mencolok. Persepsi yang demikian ini jelas keliru menurut persepsi Islam, kehidupan dunia itu amat terkait dengan kehidupan akhirat, sebab-sebab yang mendatangkan kebahagiaan hidup di dunia juga sama dengan sebab-sebab yang mendatangkan kebahagiaan hidup di akhirat.

Disisi lain ada gejala yang cukup menggembirakan bahwa arus kesadaran untuk mempelajari AlQur'an secara bersungguh-sungguh mulai mengalir dan tumbuh dikalangan ummat Islam.Kesadaran ini mendorong mereka untuk belajar membaca Al-Qur'an dan mereka juga memasukkan anakanaknya ketempat pendidikan yang di dalamnya banyak pelajaran membaca dan mengkaji Al-Qur'an Pada hakikatnya membaca Al-Qur'an bukanlah hal yang sederhana. Namun dalam membaca AlQur'an, seorang Qori (pembaca) dituntun untuk menjaga keaslian bacaan Al-Qur'an. Sebagaiman firman Allah swt dalam Q.S. Al-Qiyamah:18,

Apabila Kami telah selesai membacakannya Maka ikutilah bacaannya itu. 
Penafsiran ayat di atas berimplikasikan di samping kita harus mengamalkan syariatnya dan hukum yang terkandung di dalamnya juga yang dimaksud adalah apabila malaikat membacanya maka harus dibaca sebagaimana malaikat membacanya dengan demikian Rasul menunjuk dan memberi kepercayaan kepada beberapa sahabat untuk mengajarkanya.

Kemampuan baca Al-Qur'an adalah kesangupan atau kecakapan seseorang dalam membaca AlQur'an terutama kemampuan dalam menerapkan kaidah-kaidah ilmu tajwid dalam membaca AlQur'an sehinga bacaan itu benar. Mampu tidaknya seseorang dalammembaca Al-Qur'an sangat dipengaruhi oleh kemampuan dalam memfungsikan alat inderanya, karena malalui alat indera manusia mengenal dan mempelajari sesuatu. Oleh karena itu, panca indera merupakan modal terpenting untuk mengenal dan mempelajari huruf Al-Qur'an.

Membaca Al-Qur'an itu tidak boleh asal baca dan harus hati-hati karena tidak boleh salah cara pengucapan makhroj dan tajwidnya karena akan mempengaruhi arti dari Al-Qur'an itu. Untuk itu diperlukan metode yang cocok agar peserta didik bisa membaca Al-Qur'an dengan baik dan benar sesuai dengan hukum bacaannya.

Dalam persoalan membaca Al-Qur'an, kita ketahui bahwa Al-Qur'an adalah kitab suci berbahasa Arab dan ditulis dengan aksara Arab. Bagi orang Indonesia, hal ini merupakan suatu persoalan tersendiri. Lidah orang Indonesia berbeda dengan lidah orang Arab. Ada beberapa huruf arab yang tidak ditemukan padanannya dalam bahasa Indonesia, semisal huruf Dlad, Ha`kecil, Tsa, Kho, Dzal, dan lain sebagainya. Cara pengucapan huruf-huruf Arab mempunyai spesifikasi tersendiri. Spesifikasi tersebut terletak dari segi makhroj (tempat keluarnya huruf dalam mulut) dan sifatnya (karakteristik setiap huruf), baik sifat yang tsabitah atau yang menetap seperti sifat Hams, Jahr, Syiddah, Rakhawah, Isti`la`, Istifal, Idzlaq, Ishmat, Qalgalah, Shafir, Krir, dan sebagainya, dan ada yang bersifat `Aridlah (yang baru datang) seperti bacaan Ihkfa', Iqlab, Izhar, Idgham dan sebagainya atau yang harus dibaca tebal dan ada yang harus dibaca tipis atau yang harus dibaca panjang dan ada yang harus dibaca pendek.

Tulisan yang digunakan oleh orang Indonesia berbeda dengan tulisan Arab. Jika tulisan Indonesia (latin) dari kiri ke kanan, maka tulisan Arab adalah dari kanan ke kiri. Untuk mengatasi hal ini dibutuhkan ketekunan yang luar biasa dalam menciptakan suatu metode yang memungkinkan orang Indonesia bisa membaca Al-Qur'an dengan baik dan benar dengan waktu yang relatif cepat.

Banyak buku yang mengkaji dan membahas metode cara membaca Al-Qur'an yang ditulis oleh orang Indonesia. Dan banyak orang Indonesia, anak-anak Indonesia yang terbebas buta aksara Al-Qur'an melalui metode-metode tersebut. Kita harus bangga, karena orang Indonesia sangat kreatif.

Menurut Otong Surasman bahwa "Semua buku yang mengajarkan tentang cara membaca Al-Qur'an adalah berawal dari metode "Baghdadiyyah" yang biasanya ada pada permulaan Mushaf Al-Qur'an terbitan "Bombai" hanya saja metode ini dirasakan masih kurang sistematis, karena tidak berjenjang sesuai dengan tingkat pengetahuan para pemula". Betapapun begitu, metode ini telah bertahan puluhan tahun lamanya, dan telah melahirkan banyak ahli sebelum munculnya metode-metode baru.

Pada era tahun 70-an, muncul metode-metode baru dalam pembelajaran Al-Qur'an. Dalam pengenalan huruf-huruf Hija iyyah, ada yang langsung menggunakan huruf-huruf Arab, dan adapula yang mengunakan terlebih dahulu dengan huruf-huruf latin (Indonesia). Masa yang diperkirakan bagi seseorang untuk bisa membaca Al-Qur'an memlalui metode-metode tersebut, semakin hari semakin pendek, dari yang semula dua tahun yaitu dari umur empat sampai enam tahun, sampai ada metode yang berani menargetkan dalam beberapa pertemuan saja. Semua metode itu pasti ada kelebihan dan kekurangannya. Bagaimana pun juga hal ini sungguh suatu gejala yang menarik. Namun tentu saja yang paling penting targetnya yang ingin dicapai adalah bagaimana para pengguna buku-buku metode "cara membaca Al-Qur'an" itu, bisa membaca dengan baik dan benar, sesuai dengan kaidah-kaidah Ilmu Tajwid.

Teori saja semudah apapun dan segamblang apapun tidak cukup untuk bisa menghantarkan seseorang untuk bisa membaca Al-Qur'an dengan baik dan benar. Tapi harus dibimbing disertai praktek oleh seorang guru yang "Mutqin" bacaannya, artinya mampu melafalkan bacaan-bacaan Al-Qur'an dengan fasih, bagus, benar sesuai dengan apa yang diajarkan oleh Nabi kepada para sahabatnya. Utamanya adalah mereka yang mempunyai sanad yang berkesinambungan dari guru ke gurunya lagi sampai kepada Nabi Muhammad saw. Al-Qur'an sebagai kalamullah, perlu dijaga keaslian dan 
keotentikannya, baik dari segi bacaan, tulisannya maupun maknanya, agar terus bisa menjadi kitab rujukan kehidupan sepanjang zaman.

Sekarang di sekolah-sekolah, perhatian yang amat besar diberikan terhadap Al-Qur'an mengingat betapa pentingnya yaitu sebagai sumber ajaran dan nilai bagi umat Islam. Dalam mempelajari AlQur'an harus dimulai dengan belajar membaca Al-Qur'an, belajar membaca Al-Qur'an banyak mempunyai metode, salah satu metode membaca Al-Qur'an adalah metode Qiraati, Sebenarnya untuk menguasai penerapan metode Qiraati harus sesuai dengan ketentuan yang yang sudah ditetapkan oleh Methodology Qiraati yaitu mewujudkan guru yang harus sudah bersyahadah, semua stakeholder sekolah mendukung program metode Qiraati. Hal ini tentunya merupakan salah satu contoh kendala tersendiri yang memerlukan penyelesaian yang tentunya tidak semudah membalikkan tangan.

Sehingga hal ini penulis tertarik untuk mengadakan penelitian, dalam hal ini lebih memfokuskan pada MIT Nurul Iman, Tanah Baru, Beji, Kota Depok. Adapun pokok pembahasannya mengenai pengaruh kompetensi pedagogik guru dan penerapan metode Qiraati terhadap kemampuan baca Al-Qur'an, diantara permasalahan Qiraati adalah guru, karena gurunya harus memiliki kompetensi Qiraati yang baik dan benar sehingga hasil belajar baca Al-Qur'an tercapai dengan baik. Kajian ini akan menjadi pertimbangan para pengajar dalam kegiatan belajar mengajar di sekolah khususnya bagi pengajar yang menerapkan metode Qiraati.

Dasar pemikiran di atas dapat memberi inspirasi, bahwa keberhasilan suatu pendidikan bukan hanya metode yang hebat tapi juga harus ada guru yang hebat, maka oleh sebab itu guru Qiraati harus Tashih (Perbaikan Bacaan Al-Qur'an) dahulu. Hal ini bertujuan untuk menghapus bacaan yang salah kaprah, maka agar bermanfaat sesuai tujuannya, sebaiknya yang mengajarkan bukanlah guru yang bacanya masih salah kaprah dan jalan satu-satunya adalah dengan mengadakan Pendidikan dan Pelatihan (tashih) sebelum mengajar.

Sehingga penulis tetarik untuk melakukan penelitian mengenai "Pengaruh Kompetensi Pedagogik Guru dan Penerapan Metode Qiraati terhadap Kemampuan baca Al-Qur`an di MIT Nurul Iman, Tanah Baru, Beji, Kota Depok".

\section{Kerangka Teori \\ Kemampuan Baca Al-Quran}

Kemampuan berasal dari kata mampu yang berarti kuasa (bisa, sanggup melaksanakan sesuatu). Kemudian kata mampu tersebut mendapat awalan pe- dan akhiran-an, jadi kemampuan berati kesanggupan, kecakapan, atau kekuatan. Sehingga kemampuan membaca dapat diartikan sebagai kemampuan dasar atau bekal yang harus dimiliki oleh seorang siswa dalam belajar.

Dwi Sunar Prasetyo berpendapat bahwa membaca adalah kegiatan otak untuk mencerna dan memahami serta memaknai simbol-simbol. Sebagaimana telah terungkap dalam penegasan istilah bahwa kata kemampuan berarti melakukan sesuatu dengan terlatih atau sama dengan kepandaian, kecakapan.

Membaca adalah suatu proses (dengan tujuan tertentu) pengenalan, penafsiran dan menilai gagasan yang berkenaan dengan bobot mental atau kesadaran total seorang pembaca. Jadi, kemampuan membaca yaitu kecakapan seseorang untuk mengenal, memahami, dan menilai berbagai nuansa makna dalam teks dengan variasi tujuan.

Di antara indikator kemampuan membaca Al-Qur'an siswa adalah:

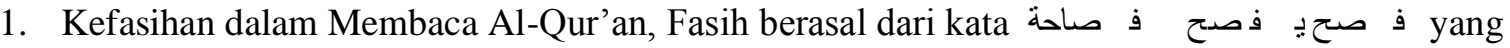
berarti berbicara dengan terang, fasih, petah lidah. Fasih dalam membaca Al-Qur'an maksudnya terang atau jelas dalam pelafalan atau pengucapan lisan ketika membaca AlQur'an. Sebagaimana Firman Allah swt. dalam Q.S. Al-Muzammil/: 4, sebagai berikut:

\section{Atau lebih dari seperdua itu. dan bacalah Al Quran itu dengan perlahan-lahan.}

2. Ketepatan pada Tajwidnya, Sebagian besar ulama mengatakan bahwa tajwid adalah suatu cabang ilmu yang sangat penting untuk dipelajari sebelum mempelajari ilmu Qiraat AlQur'an. Ilmu tajwid adalah ilmu yang digunakan untuk mengetahui bagaimana sebenarnya membunyikan huruf-huruf dengan betul, baik huruf yang berdiri sendiri manapun dalam rangkaian. Dalam ilmu tajwid diajarkan bagaimana cara melafalkan huruf yang berdiri sendiri, huruf yang dirangkaikan dengan huruf yang lain, melatih lidah mengeluarkan hurufhuruf dan makhrojnya, belajar mengucapakan bunyi yang panjang dan yang pendek, cara 
menghilangkan bunyi huruf dengan menggabungkan kepada huruf yang sesudahnya (idgham), berat atau ringan, berdesis atau tidak, mempelajari tanda-tanda berhenti dalam bacaan.

3. Ketepatan pada Makhrajnya, Sebelum membaca Al-Qur'an, sebaikya seseorang terlebih dahulu mengetahui makhraj dan sifat-sifat huruf. Sebagaimana yang dijelaskan dalam ilmu tajwid, makhraj huruf artinya membaca huruf-huruf sesuai dengan tempat keluarnya seperti di tengorokan, di tengah lidah, antara dua bibir dan lain-lain.

4. Kelancaran Membaca Al-Qur'an, Lancar adalah cepat tak ada hambatan, tidak tersendatsendat. Kelancaran membaca Al-Qur'an siswa berati siswa mampu membaca Al-Quran dengan lancar, cepat, tepat dan benar. Dalam pembelajaran membaca Al-Qur'an ketika siswa belum atau tidak lancar dalam membacanya, mestinya seorang guru tidak menaikkan ke bacaan berikutnya. Sehingga siswa tidak menghadapi tingkat kesulitan membaca yang semakin tinggi dan pada ujungnya tidak akan semakin mempersulit kerja seorang guru juga.

\section{Kompetensi Pedagogik Guru}

Kompetensi berati kewenangan (kekuasaan) untuk menentukan atau memutuskan suatu hal. Kompetensi sebagaimana yang dimaksud dalam Pasal 8 Undang-Undang Republik Indonesia nomor 14 tahun 2005, dalam bukunya yang ditulis E. Mulyasa, kompetensi yang harus dimiliki guru meliputi: kompetensi pedagogik, kompetensi kepribadian, kompetensi sosial, dan kompetensi profesional yang diperoleh melalui pendidikan profesi. Di antara keempat kompetensi tersebut salah satunya kompetensi pedogogik.

Kata pedagogik tidak akan asing di telinga guru, tetapi apakah semua guru memahami apa yang dimaksud dengan kompetensi pedagogik walau sebenarnya sudah pernah dilakukannya. Kompetensi pedagogik pada dasarnya adalah kemampuan guru dalam mengelola pembelajaran peserta didik. Kompetensi pedagogik menjadi salah satu jenis kompetensi yang harus dikuasai guru.

Kompetensi pedagogik merupakan kompetensi khas, yang akan membedakan guru dengan profesi lainnya. Penguasaan kompetensi pedagogik disertai dengan profesional akan menentukan tingkat keberhasilan proses dan hasil pembelajaran peserta didik. Kompetensi pedagogik diperoleh melalui upaya belajar secara terus menerus dan sistematis, baik pada masa pra jabatan (pendidikan calon guru) maupun selama dalam jabatan, yang didukung oleh bakat, minat dan potensi keguruan lainnya dari masing-masing individu yang bersangkutan.

Peraturan Pemerintah Nomor 74 Tahun 2008 Tentang Guru menjelaskan bahwa maksud dari Kompetensi yaitu: "Kompetensi merupakan seperangkat pengetahuan, keterampilan, dan perilaku yang harus dimiliki, dihayati, dikuasai, dan diaktualisasikan oleh guru dalam melaksanakan tugas keprofesionalan".

Kompetensi guru merupakan perpaduan antara kemampuan personal, keilmuan, teknologi, sosial, dan spiritual yang secara kaffah membentuk kompetensi standar profesi guru yang mencakup penguasaan materi, pemahaman terhadap peserta didik, pembelajaran yang mendidik, pengembangan pribadi, dan profesional.

Kompetensi pedagogik dijelaskan dalam penjelasan PP Nomor 19 Tahun 2005 Tentang Standar Nasional Pendidikan, penjelasan pasal 28 ayat 3.b dikemukakan bahwa: "Pedagogik adalah kemampuan mengelola pembelajaran peserta didik yang meliputi pemahaman terhadap peserta didik, perancangan dan pelaksanaan pembelajaran, evaluasi hasil belajar, dan pengembangan peserta didik untuk mengaktualisasikan berbagai potensi yang dimilikinya.

\section{Metode Qiraati}

Dalam proses pembelajaran, metode mempunyai peranan sangat penting dalam upaya pencapaian tujuan pembelajaran. Metode berasal dari kata method dalam bahasa Inggris yang berarti cara. Metode adalah cara yang tepat dan cepat dalam melakukan sesuatu. Secara etimologi, istilah metode adalah jalan yang harus dilalui untuk mencapai suatu tujuan, karena kata "metode" berasal dari meta yang berarti melalui dan hodus berati jalan. Namun pengertian yang hakiki dari metode tersebut adalah segala sarana yang dapat digunakan untuk mencapai tujuan yang diinginkan, baik sarana tersebut bersifat fisik seperti alat peraga, alat administrasi, dan ruang belajar untuk proses kegiatan pembelajaran berlangsung dan non fisik seperti kurikulum, dan pandangan pelaksanaan metode, lingkungan yang menunjang suksesnya pembelajaran. Metode di sini menurut peneliti diartikan 
sebagai cara yang tepat dan cepat dalam proses pembelajaran kemampuan membaca AlQur'an.Metode bukanlah suatu tujuan melainkan cara untuk mencapai tujuan sebaik-baiknya, yang dalam hal ini adalah bagaimana agar terwujudnya bimbingan baca Al-Qur'an secara sempurna.

Metode baca Al-Qur`an Qiraati ditemukan KH. Dachlan Salim Zarkasyi (W. 2001 M) dari Semarang, Jawa Tengah. Metode yang disebarkan sejak awal 1970-an, ini memungkinkan anak-anak mempelajari Al-Qur'an secara cepat dan mudah. Kiai Dachlan yang mulai mengajar Al-Qur'an pada 1963, merasa metode baca Al-Qur'an yang ada belum memadai. Misalnya metode Qa'idah Baghdadiyah dari Baghdad Irak, yang dianggap metode tertua, terlalu mengandalkan hafalan dan tidak mengenalkan cara baca tartil(jelas dan tepat, red.) KH. Dachlan kemudian menerbitkan enam jilid buku pelajaran membaca al-Qur'an untuk TK Al-Qur'an untuk anak usia 4-6 tahun pada 1 Juli 1986. Usai merampungkan penyusunannya, KH. Dachlan berwasiat, supaya tidak sembarang orang mengajarkan metode Qiraati. Tapi semua orang boleh diajar dengan metode Qiraati. Dalam perkembangannya, sasaran metode Qiraati kian diperluas. Kini ada Qiraati untuk anak usia 4-6 tahun, untuk 6-12 tahun, dan untuk mahasiswa.

Metode Qiraati disusun oleh Ustadz H. Dahlan Salim Zarkasy pada tahun 1986 bertepatan pada tanggal 1 Juli. H.M Nur Shodiq Achrom (sebagai penyusun didalam bukunya "Sistem Qoidah Qiraati" Ngembul, Kalipare), metode ini ialah membaca Al-Qur'an yang langsung memasukkan dan mempraktekkan bacaan tartil sesuai dengan qoidah ilmu tajwid sistem pendidikan dan pengajaran metode Qiraati ini melalui system pendidikan berpusat pada murid dan kenaikan kelas/jilid tidak ditentukan oleh bulan/tahun dan tidak secara klasikal, tapi secara individual (perseorangan).

Metode Qiraati mempunyai keistimewaan yaitu karena cara mengajarkanya membaca Al-Qur'an langsung memasukan dan memperaktekan bacaan tartil sehinga siswa tidak hanya bisa membaca tapi mengenal huruf-huruf Al-Qur`an, dan pengajar metode Qiraati harus memiliki syahadah Qiraati sehinga terjaga mutu dari setiap pengajar, Dasar pemikiran di atas dapat memberi inspirasi, bahwa keberhasilan suatu pendidikan bukan hanya metode yang hebat tapi juga harus ada guru yang hebat, maka oleh sebab itu guru Qiraati harus Tashih (Perbaikan Bacaan Al-Qur'an) dahulu. Hal ini bertujuan untuk menghapus bacaan yang salah kaprah, maka agar bermanfaat sesuai tujuannya, sebaiknya yang mengajarkan bukanlah guru yang bacanya masih salah kaprah dan jalan satu-satunya adalah dengan mengadakan Pendidikan dan Pelatihan (tashih) sebelum mengajar.

\section{Metode Penelitian}

Tempat Dan Waktu Penelitian

Tempat penelitian adalah lokasi penelitian yang dilaksanakan atau dilakukan.Penelitian ini bertempat di Madrasah Ibtidaiyah Terpadu Nurul Imana, yang beralamat di Jalan Karya Bakti N0. 26 Tanah baru Kecamatan Beji Kota Depok.

Waktu adalah saat atau masa penelitian ketika dilaksanakan.Pelaksanaan penelitian ini pada saat semester genap tahun ajaran 2014. Penelitian ini dilakukan untuk mengetahui pengaruh kompetensi pedagogik guru, penerapan metode Qiraati terhadap kemampuan baca Al-Qur`an. Proses penyebaran dan pengumpulan data dilakukan terhitung mulai tanggal 13 Mei sampai dengan 10 Oktober 2014 dengan menyebarkan sebanyak 115 kuesioner.

Populasi dan Sampel

Populasi adalah gabungan dari seluruh elemen yang berbentuk peristiwa, hal atau orang yang memiiki karakteristik serupa yang menjadi pusat perhatian penelitian, karenanya dipandang sebagai semesta penelitian. Populasi dalam penelitian ini adalah penulis mengambil sampel dari 450 siswa Madrasah Ibtidaiya Terpadu (MIT) Nurul Iman, Tanah Baru-Depok. Apabila subjeknya kurang dari seratus siswa maka lebih baik diambil seluruhnya, sehingga penelitiannya merupakan penelitian populasi secara mutlak, jika jumlah subjeknya besar bisa diambil 10-15\% atau 20-25\% atau lebih.

Sampel merupakan subjek dari populasi, terdiri dari beberapa anggota populasi. Mengingat jumlah populasi banyak, maka layak untuk diambil beberapa persen untuk dijadikan sampel tanpa harus mengambil sampel dalam jumlah tertentu sehingga sampel dari penelitian ini adalah $25 \%$ dari jumlah populasi.

Populasi adalah wilayah generalisasi yang terdiri atas subjek atau objek yang mempunyai kuantitas dan kualitas karakteristik tertentu yang ditetapkan oleh peneliti untuk dipelajari dan ditarik 
kesimpulanya. Berdasarkan objeknya maka populasi yang akan dijadikan populasi penelitian adalah sebagian dari siswa MIT Nurul Iman, dengan jumlah populasi sebanyak 450 orang.

Sampel adalah bagian dari jumlah dan karekteristik yang dimiliki oleh populasi tersebut. Bila populasi besar dan peneliti tidak mungkin mempelajari semua yang ada pada populasi, misalnya karena keterbatasan dana, tenaga, dan waktu maka peneliti boleh mengambil sampel 10-15\%, 15-25\% atau $50 \%$ dari populasi yang ada. Adapun yang menjadi sampel dalam penelitian ini adalah $25 \%$ dari jumlah populasi yang ada, yaitu $450 \times 25 \%=115$ orang.

Variabel Penelitian

Dalam penelitian ini terdapat tiga variabel yaitu variabel bebas (dependent) tentang kompetensi pedagogik guru (X1), variabel bebas (dependent) tentang penerapan metode Qiraati (X2), dan variabel terikat tentang kemampuan baca Al-Qur'an (Y).Ketiga variabel tersebut selanjutnya dijabarkan dalam beberapa dimensi, dari dimensi dijabarkan dalam beberapa indikator berdasarkan teori yang dikemukakan para ahli.

Jenis Penelitian

Penelitian ini dilakukan dengan pendekatan kuantitatif. Penelitian kuantitatif adalah suatu proses menemukan pengetahuan yang menggunakan data berupa angka sebagai alat menemukan keterangan mengenai apa yang ingin diketahui peneliti. Angka-angka yang terkumpul sebagai hasil penelitian kemudian dapat dianalisis menggunakan metode statistik.

Penelitian ini mengkaji pengaruh kompetensi pedagogik guru, penerapan metode Qiraati terhadap kemampuan baca Al-Qur'an siswa MIT Nurul Iman, Tanah Baru-Depok. Penelitian ini termasuk kategori penelitin expost facto, disebut penelitian expost fakto karena dalam penelitian ini berhubungan dengan variabel yang telah terjadi dan tidak perlu memberikan perlakuan terhadap variabel yang diteliti. Karena penelitian tidak memanipulasi keadaan variabel yang ada dan langsung mencari keberadaan hubungan dan tingkat hubungan variabel yang direflesikan dalam koefisien korelasi. Dalam penelitian ini variabel bebas yaitu kompetensi pedagogik guru, variabel terikat yaitu penerapan metode Qiraati kemudian dihubungkan dengan untuk mencari pengaruh variabel bebas terhadap varibel terikatnya.

Variabel yang digunakan dalam penelitian ini adalah pendekatan kuantitatif dengan jenis penelitian korelasional. Penelitian korelasional merupakan penelitian yang dimaksudkan untuk mengetahui ada tidaknya hubungan antara dua variabel atau beberapa variabel. Hal senada juga diungkapkan oleh Faisal, penelitian korelasi adalah hubungan dua atau lebih variabel yang berpasangan, hubungan antara dua perangkat data atau lebih, yang mana derajat hubungnya bisa diukur dan digambarkan dengan kofiensi korelasi.

Tujuan teknik korelasi adalah: (1) untuk mencari bukti berdasarkan hasil pengumpulan data, apakah terdapat hubungan antar variabel atau tidak, (2) untuk menjawab pertanyaan apakah hubungan antar variabel tersebut kuat, sedang atau lemah, dan (3) ingin memperoleh kepastian secara matematis apakah hubungan anatar variabel merupakan hubungan yang menyakinkan (signifikan) atau hubungan yang tidak menyakinkan.

\section{Hasil dan Pembahasan}

Berdasarkan tinjauan pustaka yang telah dibahas dan kajian empiris di atas, berikut akan dibahas hasil penelitian sebagai upaya untuk melakukan sintesis antara kajian teori dengan temuan empiris. Adapun secara rinci pembahasan hasil analisis dan pengujian hipotesis penelitian diuraikan sebagai berikut:

a. Pengaruh Kompetensi Pedagogik terhadap Kemampuan Baca Al-Qur'an. Dari hasil pengujian hipotesis pertama dapat disimpulkan bahwa terdapat pengaruh langsung positif kompetensi pedagogik terhadap kemampuan baca Al-Qur'an dengan nilai koefisien korelasi sebesar 0,738 dan nilai koefisien jalur sebesar 0,612. Ini memberikan makna kompetensi pedagogik akan berpengaruh langsung terhadap kemampuan baca Al-Qur'an. Berdasarkan uraian di atas, dapat diasumsikan bahwa kompetensi pedagogik diduga memiliki pengaruh langsung terhadap kemampuan baca Al-Qur'an, karena supervisi yang tepat dan berkelanjutan sangat berpengaruh terhadap kemampuan baca Al-Qur'an.

b. Pengaruh Penerapan Metode Qiraati terhadap Kemampuan Baca Al-Qur'an. Dari hasil pengujian hipotesis pertama dapat disimpulkan bahwa terdapat pengaruh langsung positif penerapan metode Qiraati terhadap kemampuan baca Al-Qur'an dengan nilai koefisien korelasi sebesar 
0,570 dan nilai koefisien jalur sebesar 0,221. Ini memberikan makna kompetensi pedagogik akan berpengaruh langsung terhadap kemampuan baca Al-Qur'an. Berdasarkan uraian tersebut di atas, dapat diasumsikan bahwa penerapan metode Qiraati diduga berpengaruh langsung positif terhadap kemampuan baca Al-Qur'an.

c. Pengaruh Kompetensi Pedagogik terhadap Penerapan Metode Qiraati Dari hasil pengujian hipotesis pertama dapat disimpulkan bahwa terdapat pengaruh langsung positif kompetensi pedagogik terhadap penerapan metode Qiraati dengan nilai koefisien korelasi sebesar 0,571 dan nilai koefisien jalur sebesar 0,571. Ini memberikan makna kompetensi pedagogik akan berpengaruh langsung terhadap kemampuan baca Al-Qur'an. Dari pernyataan tersebut disimpulkan bahwa jika supervisi dilaksanakan secara tepat dan berkelanjutan, maka penerapan metode Qiraati pun akan semakin meningkat. Dengan demikian dari berbagai pendapat di atas, dapat diduga bahwa terdapat pengaruh antara kompetensi pedagogik dengan penerapan metode Qiraati.

Dari ketiga hipotesis terbut bahwa Kompetensi Pedagogik merupakan kopetensi khas yang akan membedakan guru dengan profesi lainya, penguasaan kopetensi pedagogik disertai dengan kemamupuan dalam penerapan metode Qiraati yang baik akan menentukan tingkat keberhasilan proses dan keberhasilan kemampun baca Al-Qur`an peserta didik, kompetensi pedogogik dan penerapan diperoleh melului upaya belajar secara terus menerus dan sitematis, baik pada masa pra jabatan (Pendidikan Calon Guru) maupun selama dalam jabatan yang didukung oleh bakat, minat dan potensi keguruan lainya dari masing-masing individu yang bersangkutan.

\section{Kesimpulan}

Kesimpulan

Penelitian ini memiliki tujuan untuk mengetahui pengaruh kompetensi pedagogik guru dan penerapan metode Qiraati terhadap kemampuan baca A-Qur`an. Berdasarkan hasil penelitian yang telah dilakukan maka dapat diambil suatu kesimpulan sebagai berikut:

a. Terdapat pengaruh yang signifikan kompetensi pedagogik guru terhadap kemampuan baca AlQur`an di Madrasah Ibtidaiyah Terpadu Nurul Iman, Beji, Tanah Baru sebanyak 73,8\% dan terdapat sisa $26,2 \%$ dipengaruhi oleh variabel lainnya.

b. Terdapat pengaruh yang signifikan dari penerapan metode Qiraati terhadap kemampuan baca AlQuran di Madrasah Ibtidaiyah Terpadu Nurul Iman, Beji, Tanah Baru sebanyak 57,0\% dan terdapat sisa $43,0 \%$ yang dipengaruhi oleh variabel lainnya.Terdapat pengaruh yang signifikan kompetensi pedagogik guru dan penerapan metode Qiraati secara bersama-sama terhadap kemampuan baca Al-Quran di Madrasah Ibtidaiyah Terpadu Nurul Iman, Beji, Tanah Baru sebanyak $57,1 \%$ dan terdapat sisa $42,9 \%$ yang dipengaruhi oleh variabel lainnya.

c. Dari kedua variabel yang mempengaruhi kemampuan baca Al-Quran di Madrasah Ibtidaiyah Terpadu Nurul Iman, Beji, Tanah Baru, Depok. Yang paling dominan terhadap kemampuan baca Al-Qur'an adalah kompetensi pedagogik guru, semakin tinggi pengaruh kompetensi pedagogik guru maka akan semakin tinggi juga peningkatan kemampuan baca Al-Qur`an.

Implikasi

Berdasarkan hasil penelitian yang didapat maka dapat dikemukakan implikasi sebagai berikut:

1.Implikasi Teoritis, Berdasarkan analisis data dan hasil penelitian, terdapat pengaruh yang signifikan kompetensi pedagogik guru dan penerapan metode Qiraati terhadap kemampuan baca Al-Qur`an, dasar pemikiran di atas membawa inspirasi bahwa keberhasilan suatu pendidikan bukanya hanya metode yang hebat tapi juga harus ada guru yang hebat.

Kompetensi pedagogik pada dasarnya adalah kemampuan dalam mengelolah pembelajaran peserta didik karena kompetensi pedagogik merupakan kompetensi khas yang akan membedakan guru dengan profesi lainya, penguasaan kompetensi pedagogik disertai dengan profesional akan menentukan tingkat keberhasilan proses dan hasil pembelajaran peserta didik.

Dalam proses pembelajaran, metode mempunyai peranan sangat penting dalam upaya pencapaian tujuan pembelajaran. Metode berasal dari kata method dalam bahasa Inggris yang berarti cara. Metode adalah cara yang tepat dan cepat dalam melakukan sesuatu. Secara etimologi, istilah metode adalah jalan yang harus dilalui untuk mencapai suatu tujuan, karena kata "metode" berasal dari meta yang berarti melalui dan hodus berati jalan. Namun pengertian yang hakiki dari metode tersebut adalah 
segala sarana yang dapat digunakan untuk mencapai tujuan yang diinginkan, baik sarana tersebut bersifat fisik seperti alat peraga, alat administrasi, dan ruang belajar untuk proses kegiatan pembelajaran berlangsung dan non fisik seperti kurikulum, dan pandangan pelaksanaan metode, lingkungan yang menunjang suksesnya pembelajaran. Metode di sini menurut peneliti diartikan sebagai cara yang tepat dan cepat dalam proses pembelajaran kemampuan membaca Al-Qur'an.

Dari pengertian tentang kompetensi pedagogik dan penerapan metode Qiraati, sangat jelas bahwa keduanya berpengaruh terhadap kemampua baca Al-Qur'an, adapun pengaruhnya adalah: untuk variabel kompetensi pedagogik guru sebanyak $73,8 \%$ sedangkan variabel penerapan metode Qiraati berpengaruh sebanyak 57,0\% adapun secara bersamaan berpengaruh sebanyak $57,1 \%$.

Implikasi Praktis

Implikasi hasil penelitian ini adalah dalam upaya meningkatkan kemampuan baca Al-Quran maka penerapan metode Qiraati harus terus ditingkatkan. Untuk meningkatkan penerapan metode Qiraati dapat dilakukan dengan meningkatkan kualitas kompetensi pedagogik guru, serta kualitas dan kuantitas lingkungan kerja. Peningkatan kopetensi pedagogik guru dapat diperoleh melalui upaya belajar secara terus menerus dan sistematis, baik pada masa pra jabatan (pendidikan calon guru) maupun selama dalam jabatan, yang didukung oleh bakat, minat dan potensi keguruan lainnya dari masing-masing individu yang bersangkutan.

Kompetensi pedagogik dijelaskan dalam penjelasan PP Nomor 19 Tahun 2005 Tentang Standar Nasional Pendidikan, penjelasan pasal 28 ayat 3.b dikemukakan bahwa: "Pedagogik adalah kemampuan mengelola pembelajaran peserta didik yang meliputi pemahaman terhadap peserta didik, perancangan dan pelaksanaan pembelajaran, evaluasi hasil belajar, dan pengembangan peserta didik untuk mengaktualisasikan berbagai potensi yang dimilikinya. dalam hal ini kepala sekolah harus berupaya menyediakan ligkungan kerja yang memadai untuk mendukung kinerja guru dengan cara memenuhi fasilitas seperti media dan sumber pebelajaran yang dibutuhkan oleh guru, serta menciptakan hubungan sosial yang baik antara warga sekolah. Dan setelah semua media dan sumber pembelajaran lengkap guru harus berupaya untuk meningkatkan metode pembelajaran agar tercipta kelas yang kondusif dan pembelajaran yang menyenangkan,sehingga dengan demikian prestasi siswa akan meningkat.

\section{Saran}

Berdasarkan kesimpulan dan implikasi diatas, dapat diambil saran beberapa hal berikut:

a. Pada hasil penelitian tentang pengaruh kompetensi pedagogik guru, terdapat pengaruh yang signifikan terhadap kemampuan baca Al-Qur`an, namun perlu dipertahankan dan ditingkatkan kembali. dan hal ini sesuai dengan teori yang telah ada bahwa penguasaan kompetensi pedagogik disertai dengan profesional akan menentukan tingkat keberhasilan proses dan hasil pembelajaran peserta didik.

b. Penerapan metode Qiraati juga memiliki pengaruh yang signifikan terhadap kemampuan baca AlQur`an dan perlu dipertahankan juga ditingkatkan, hal ini juga sesuai dengan teori yang telah ada, karena semakin tinggi tingkat penerapan metode Qiraati maka akan semakin tinggi pula kemampuan baca Al-Qur`an.

c. Pengaruh Kompetensi pedagogik guru memiliki pengaruh yang lebih dominan dibandingkan penerapan metode Qiraati, karena guru adalah sumber keberhasilan.

d. Perlu dilakukan penelitian lanjutan dengan menggunakan variabel-variabel yang berbeda agar dapat terinventaris berbagai variabel yang dapat mempengaruhi peningkatan kinerja guru.

e. Hasil penelitian ini diharapkan sebagai bahan informasi yang berguna bagi guru dalam rangka meningkatkan kemampuan baca Al-Qur’an di sekolah. Bagi para guru disarankan lebih memperhatikan dan meningkatkan kompetensi pedagogik guru. 


\section{DAFTAR PUSTAKA}

Arikunto, Suharsimi. Prosedur Penelitian. Bandung: Rineka Cipta, 1993.

Ash Shidieqy, Teunku Muhammad Hasbi. Ilmu-ilmu Al-Quran, Semarang: Pustaka Rizki Putra, 2002.

Chatib, Munif. Gurunya Manusia. Bandung: Penerbit Kaifa PT Mizan Pustaka, 2011.

Daradjat, Zakiah. Kepribadian Guru. Jakarta: PT Bulan Binatang, 2005.

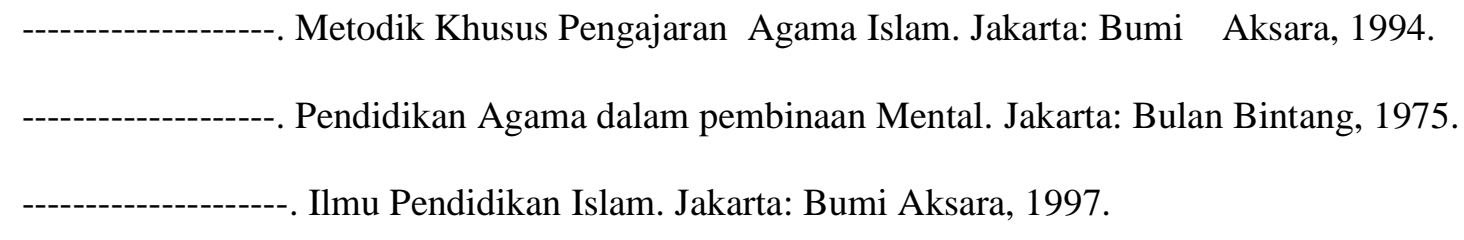

Departemen Agama. UU RI No.14 Tahun 2005 Tentang Guru dan Dosen, Serta UU RI No.20 Tahun 2003 Tentang Sisdiknas.

Depdiknas. 2006. Peraturan Pemerintah N0. 14 Tahun 2005 tentang Guru dan dosen. http://www.depdiknas.go.id/inlink.

E. Mulyasa. Kurikulum Tingkat Satuan Pendidikan. Bandung: PT. Remaja Rosda Karya, 2007.

Fathoni, Ahmad. Kaidah Qiraat Tujuh. Jakarta: Darul Ulum Press, 2007.

Ferdinand, AT. Metode Penelitian Manajemen. Semarang: BP Undip, 2006.

Guntur Tarigan, Henry. Metodologi Pengajaran Bahasa 2. Bandung: Angkasa 1991.

Halim, Muhammad Abdul. Memahami Al-Qur'an. Bandung: Marja, 2002.

Hasan, Fuad. Depdikbud Hadapi Kendala yang Sama. Kompas, 1992.

http://akhmadsudrajat.wordpress.com/2012/01/29/kompetensi-pedagogilk-guru, diunduh hari Selasa, 18 Maret 2014, Pukul 08.52.

http://cmslokomedia.widiyanto.com/berita-141-7-aspek-kompetensi-pedagogik-guru.html, diunduh hari selasa, 18 Maret 2014, Pukul 08.52.

http://literaturkti.blogspot.com/2012/09/pengertian-hasil-belajar.html, diunduh hari Selasa, 18 Maret 2014, Pukul 09.17.

Isa, Kamal Muhammad. Manajemen Pendidikan Islam. Jakarta: PT. Fikahati Anesta, 1994.

M. Zainuddin. Paagdima Pendidikan Terpadu. Malang: UIN Malang Press, 2008.

Mubarok, Ahmad. Jiwa Dalam Al-Qur`an. Jakarta: Paramadina, 2000.

Munir, Ahmad dan Sudarsono. Ilmu Tajwid dan Seni baca Al-Quran. Jakarta: Rineka Ciptaa, 1994. 
Murad, Khuram. Generasi Qurani Meniti Jalan dan Menyikapi Kalam Allah. Surabaya: Risalah Gusti, 1992.

Peraturan Pemerintah Nomor 74 tahun 2008 tentang Guru.

Permendiknas No.11 Tahun 2005Tentang Buku Teks Pelajaran dan PP RI No.19 Tahun 2005 Tentang SNP.

Prasetyo, Dwi Sunar. Rahasia mengajarkan Gemar Membaca pada Anak Sejak Dini. Jogjakarta: Penerbit Think, 2008.

Purwanto, M Ngalim. Prinsip-prinsip dan Teknik Evaluasi Pengajaran. Jakarta: Rieneka Cipta, 2005.

Qohar, Mujamil. Manajemen Pendidikan Islam. Jakarta: Erlanga, 2007.

Shihab, M. Quraish. Membumikan Al-Quran. Jakarta: Lentera, 2006.

Shihab, M. Quraish. Wawasan Al-Qur`an. Bandung: Mizan, 2000.

Slameto. Psikologi Belajar Mengajar. Jakarta: Rineka Cipta, 1995.

Surapto, Choirul Fuad Yusuf, dkk. Budaya Sekolah dan Mutu Pendidikan. Jakarta: PT Pena Citasatria, 2008.

Surasman, Otong. BBM Al-Qur'an Metode As-Surasmaniyyah. Jakarta: Gema Insani, 2013.

Team Penyusun Phoenix. Kamus besar Bahasa Indonesia. Jakarta: PT Media Pustaka Phoenix, 2008.

Umdira, Abdur Rahman. Metode Al-Qur'an dalam Pendidikan. Jakarta: Ciputat Pres, 2002.

Undang-undang Republik Indonesia No. 14 Tahun 2005 tentang Guru dan Dosen. Bandung: Citra Umbara, 2006.

Wajih, Ahmad Alwafa. Metodholgy Qiroaty.

Yunus, Mahmud. Kamus Arab Indonesia. Jakarta: PT Hidakarya, 1989. 